\title{
ANALISIS PELAPORAN KEUANGAN DI YAYASAN AS-SALAM MANADO (BERDASARKAN PSAK 45 DAN PSAK 101)
}

\author{
Wahyuningsih $^{1}$, Herman Karamoy ${ }^{2}$, Dhullo Afandy $^{3}$ \\ ${ }^{1,2,3}$ Fakultas Ekonomi dan Bisnis, Jurusan Akuntansi, Universitas Sam Ratulangi, Jl.Kampus Bahu, Manado, \\ 95115, Indonesia \\ E-mail : wahyuningsss@gmail.com
}

\begin{abstract}
The financial statements are important media in the process of making economic decisions. There are several rules on the preparation of financial statements, one of which is the financial statements for non-profit entities and sharia entities. The purpose of this study is to analyze Financial Reporting As-Salam Manado Foundation in accordance with the concept of financial statements based on PSAK 45 and PSAK 101. In this study the type of data used is qualitative data, while for data sources using primary data and secondary data, the analytical method used is descriptive analysis. Based on the result of the research, it is concluded that the recording and presentation of the foundation's financial statements are still not in accordance with the applicable regulations, which are PSAK 45 and PSAK 101.

Keywords: Non-profit Financial Statements
\end{abstract}

\section{PENDAHULUAN}

Secara garis besar tujuan organisasi yang dikelola lembaga pendidikan dapat dibedakan menjadi dua, yaitu : memperoleh laba (bisnis), sedangkan yang lainnya adalah tidak berorientasi laba (nirlaba). Baik itu lembaga pendidikan swasta maupun yang didirikan oleh pemerintah seperti sekolah-sekolah negeri pada umumnya. Namun, akuntansi tidak saja digunakan dalam praktek bisnis, tetapi juga berbagai kehidupan. Pencatatan, penjurnalan, serta perhitungan anggaran juga termasuk dalam sistem akuntansi. Tanpa disadari semua bidang membutuhkan akuntansi, termasuk organisasi nirlaba (nonprofit).

Sebagaimana halnya organisasi bisnis, organisasi nirlaba seperti yayasan juga membutuhkan jasa akuntansi. Baik untuk menghasilkan informasi keuangan maupun untuk meningkatkan mutu pengawasan yayasan yang bersangkutan. Akan tetapi karena sifat yayasan atau nirlaba berbeda dengan organisasi laba lainnya, maka sifat akuntansinya pun berbeda. Bagi yayasan, tujuan utamanya adalah memberikan pelayanan kepada masyarakat, sedangkan bagi entitas bisnis tujuan utamanya adalah mencari laba (profit) semata.

Pada perekonomian modern, laporan keuangan merupakan media penting dalam proses pengambilan keputusan ekonomis. Laporan keuangan perusahaan lazim diterbitkan secara periodik bisa tahunan, semesteran, triwulan, bulanan, bahkan bisa harian. Pengguna laporan keuangan entitas nirlaba memiliki kepentingan bersama yang tidak berbeda dengan entitas bisnis, yaitu untuk menilai: (a) jasa yang diberikan oleh entitas nirlaba dan kemampuannya untuk terus memberikan jasa tersebut; (b) cara manajer melaksanakan tanggung jawab dan aspek kinerjanya (Harahap, 2015).

Dalam tiga dekade terakhir, lembaga keuangan telah meningkatkan volume dan nilai transaksi berbasis syariah yang tentunya meningkatkan kebutuhan terhadap akuntansi syariah. Akuntansi syariah diperlukan untuk mendukung kegiatan yang harus dilakukan sesuai syariah, karena tidak mungkin dapat menerapkan akuntansi yang sesuai dengan syariah jika transaksi yang akan dicatat oleh proses akuntansi tersebut tidak sesuai dengan syariah (Nurhayati dan Wasilah, 2015:3). 
Dalam laporan keuangan syariah terdiri dari beberapa komponen penting, diantaranya adalah Laporan Sumber dan Penggunaan Dana Zakat selama periode, serta Laporan Sumber dan Penggunaan Dana Kebajikan selama periode. Kedua komponen tersebut merupakan komponen yang penting dan harus disajikan dalam sebuah entitas syariah sesuai dengan pernyataan pada PSAK 101 paragraf 14: "Jika entitas syariah belum melaksanakan fungsi sosial secara penuh, maka entitas syariah tetap menyajikan Laporan Sumber dan Penyaluran Dana Zakat, dan Laporan Sumber dan Penggunaan Dana Kebajikan”.

Yayasan dapat dikatakan sebagai suatu lembaga yang didirikan bukan untuk mencari laba semata (nirlaba). Yayasan adalah suatu badan hukum yang mempunyai maksud dan tujuan bersifat sosial, keagamaan dan kemanusiaan, didirikan dengan memperhatikan persyaratan formal yang ditentukan dalam undang-undang. Di Indonesia, yayasan diatur dalam Undang-Undang Nomor 28 Tahun 2004 tentang Perubahan atas Undang-Undang Nomor 16 Tahun 2001 tentang Yayasan. Rapat paripurna DPR pada tanggal 7 September 2004 menyetujui undang-undang ini, dan Presiden RI Megawati Soekarnoputri mengesahkannya pada tanggal 6 Oktober 2004. Yayasan pada umumnya termasuk dalam organisasi nirlaba, sehingga laporan keuangannya mengacu pada PSAK 45, namun untuk yayasan yang berlandaskan Islam, harus terdapat Laporan Sumber dan Penggunaan Dana Zakat dan Dana Kebajikan, sebab dalam Islam, dana zakat merupakan kewajiban yang harus dikeluarkan setiap muslim. Karena dalam PSAK 45 tidak membahas dana zakat dan dana kebajikan, maka untuk menyesuaikan laporan keuangan sesuai syariat Islam, acuan yang harus diikuti adalah PSAK syariah khususnya untuk laporan keuangannya yang terdapat pada PSAK 101. Dana zakat dan dana kebajikan merupakan komponen yang ada dalam Laporan Keuangan Syariah. Berdasarkan Standar Akuntansi Syariah, khususnya pada PSAK 101, terdapat pernyataan yang mengatur pelaporan Sumber dan Penggunaan Dana Zakat serta Sumber dan Penggunaan Dana Kebajikan. Jika suatu organisasi nirlaba merupakan organisasi syariah, maka acuan yang sepatutnya diikuti adalah PSAK 45 serta PSAK 101 khusunya pada laporan sumber dan penggunaan dana zakat dan dana kebajikan.

Organisasi nirlaba di Indonesia saat ini masih cenderung menekankan pada prioritas kualitas program dan tidak terlalu memperhatikan pentingnya sistem pengelolaan keuangan. Padahal sistem pengelolaan keuangan yang baik merupakan salah satu indikator utama akuntabilitas dan transparansi sebuah lembaga. Untuk membangun sistem pengelolaan keuangan yang andal dibutuhkan pengetahuan, keterampilan dan pengalaman yang cukup. Yayasan As-Salam merupakan suatu organisasi nirlaba yang sudah cukup lama di Manado. Jika dilihat dari aktivitas yayasan pada bidang pendidikan, seharusnya pelaporan keuangan yayasan sudah harus memadai untuk dapat dibandingkan dengan laporan keuangan organisasi lainnya. Namun, penyususan laporan keuangan yang dilakukan oleh yayasan masih sangat sederhana dan belum akurat. Hal ini menyebabkan laporan keuangan menjadi kurang relevan sehingga informasi keuangan yang diperoleh pun masih belum andal.

\section{TINJAUAN PUSTAKA}

\subsection{Akuntansi}

Menurut Mulyadi (2014:2) "Akuntansi adalah proses pencatatan, penggolongan, dan penyajian dengan cara-cara tertentu, transaksi keuangan yang terjadi dalam perusahaan atau organisasi lain serta penafsiran terhadap hasilnya" Akuntansi adalah suatu aktivitas jasa yang terdiri dari mencatat, mengklasifikasikan, dan melaporkan kejadian atau transaksi ekonomi yang akhirnya akan menghasilkan suatu informasi keuangan yang akan dibutuhkan oleh pihak-pihak tetentu untuk pengambilan keputusan (Sujarweni, 2015:1).

\subsection{Akuntansi Keuangan}

Menurut Suryadi, (2013:1) akuntansi keuangan adalah akuntansi yang tujuan pokoknya menghasilkan laporan keuangan yang biasanya terdiri dari Neraca dan Laba / Rugi. 
Akuntansi keuangan menyajikan informasi terutama untuk kepentingan pihak eksternal entitas ekonomi. Di antara para pihak eksternal tersebut, pengguna yang utama adalah para pemilik perusahaan (pemegang saham) dan para kreditor (Sodikin \& Riyono, 2015: 5).

Menurut Harahap (2015: 127), Akuntansi keuangan memberikan informasi yang bersifat baku, terstandar dan bertujuan umum (general purpose). Format informasinya sudah memiliki pola yang ditetapkan lembaga resmi. Di Indonesia disebut SAK (Standar Akuntansi Keuangan) dikeluarkan oleh IAI, di Amerika disebut GAAP (General Accepted Accounting Principle) yang dikeluarkan oleh FASB (Financial Accounting Standard Board) dengan nama FASB Statement.

\subsection{Laporan Keuangan}

Menurut Ikatan Akuntan Indonesia (IAI) dalam Standar Akuntansi Keuangan (PSAK 1, par 09), Laporan keuangan merupakan penyajian terstruktur dari posisi keuangan dan kinerja keuangan suatu entitas. Tujuan laporan keuangan yaitu untuk memberikan informasi mengenai posisi keuangan, kinerja keuangan, dan arus kas entitas yang bermanfaat bagi sebagian besar pengguna laporan keuangan dalam pembuatan keputusan ekonomi. Laporan keuangan menunjukkan hasil pertanggung-jawaban manajemen atas penggunaan sumber daya. Dalam rangka mencapai tujuan tersebut, laporan keuangan menyajikan informasi mengenai entitas yang meliputi:

1. Aset;

2. Liabilitas;

3. Ekuitas;

4. Penghasilan dan beban (termasuk keuntungan dan kerugian);

5. Kontribusi dari dan distribusi kepada pemilik dalam kapasitasnya sebagai pemilik;

6. Arus kas.

Informasi tersebut beserta informasi lainnya, yang terdapat dalam catatan atas laporan keuangan membantu pengguna laporan keuangan dalam memprediksi arus kas masa depan entitas, khususnya dalam hal waktu dan kepastian diperolehnya arus kas masa depan. Laporan keuangan menggambarkan kondisi keuangan, serta hasil usaha suatu perusahaan pada saat tertentu. Adapun jenis laporan keuangan yang biasa dikenal adalah Neraca serta Laporan Laba/Rugi, atau hasil usaha, Laporan Arus Kas, Laporan Perubahan Posisi Keuangan. Laporan keuangan merupakan media yang paling penting untuk menilai prestasi dan kondisi ekonomis suatu perusahaan (Harahap, 2015:105).

\subsection{Organisasi Nirlaba}

Menurut Wikipedia, Organisasi nirlaba adalah organisasi yang bersasaran pokok untuk mendukung suatu isu atau perihal dalam menarik perhatian publik untuk suatu tujuan yang tidak komersil, tanpa ada perhatian terhadap hal-hal yang bersifat mencari laba (moneter). Organisasi nirlaba terdiri dari gereja, sekolah negeri, derma publik, rumah sakit dan klinik publik, organisasi politis, bantuan masyarakat dalam hal perundang-undangan, organisasi jasa sukarelawan, serikat buruh, asosiasi profesional, institut riset, museum, dan beberapa para petugas pemerintah. Karakteristik Organisasi Nirlaba menurut Rahayu (2017) adalah sebagai berikut:

1. Sumber daya organisasi berasal dari penyumbang yang tidak mengharapkan pembayaran kembali atau manfaat ekonomi yang sebanding dengan jumlah sumber daya yang diberikan.

2. Menghasilkan barang dan jasa tanpa bertujuan mendapatkan laba, dan jika suatu organisasi menghasilkan laba, maka jumlah laba tidak pernah dibagikan kepada para pendiri atau pemilik organisasi tersebut.

3. Tidak ada kepemilikan seperti pada organisasi bisnis, dalam arti bahwa kepemilikan dalam organisasi nirlaba tidak dijual, dialihkan, atau ditebus kembali, atau kepemilikan 
tersebut tidak mencerminkan proporsi pembagian sumber daya organisasi pada saat likuidasi atau pembubaran organisasi.

Organisasi nirlaba membutuhkan pengelolaan yang berbeda dibandingkan dengan organisasi profit dan pemerintahan. Pengelolaan organisasi nirlaba serta kriteria pencapaian kinerja organisasi tidak berdasar pada pertimbangan ekonomi semata, tetapi sejauh mana masyarakat yang dilayaninya diberdayakan berdasarkan dengan konteks hidup dan potensi kemanusiaannya. Sifat sosial dan kemanusiaan sejati merupakan ciri khas pelayanan organisasi nirlaba. Manusia menjadi pusat sekaligus agen perubahan dan pembaruan masyarakat untuk mengurangi kemiskinan, menciptakan kesejahteraan, kesetaraan gender, keadilan, dan kedamaian, bebas dari konfilk dan kekerasan. Kesalahan dan kurangnya pengetahuan dalam mengelola organisasi nirlaba, justru akan menjebak masyarakat hidup dalam kemiskinan, ketidakberdayaan, ketidaksetaraan gender, konflik dan kekerasan sosial (Putri, 2017).

\subsubsection{Yayasan: Pondok Pesantren}

Menurut Wikipedia, Yayasan merupakan badan hukum yang mempunyai maksud dan tujuan bersifat sosial, keagamaan dan kemanusiaan, didirikan dengan memperhatikan persyaratan formal yang ditentukan dalam undang-undang. Di Indonesia, yayasan diatur dalam Undang-Undang Nomor 28 Tahun 2004 tentang Perubahan atas Undang-Undang Nomor 16 Tahun 2001 tentang Yayasan. Rapat paripurna DPR pada tanggal 7 September 2004 menyetujui undang-undang ini, dan Presiden RI Megawati Soekarnoputri mengesahkannya pada tanggal 6 Oktober 2004.

Yayasan merupakan salah satu jenis dari organisasi nirlaba. Yayasan memiliki orientasi yang berbeda-beda tergantung tujuan yayasan tersebut. Dalam berbagai tempat, kebanyakan yayasan yang sering kita jumpai adalah yayasan yang berorientasi pendidikan dan keagamaan, atau bahkan keduanya, seperti sekolah, taman pengajian, serta Pondok Pesantren.

Sebagai lembaga kemasyarakatan yang bertujuan untuk mensyiarkan agama Islam, pesantren membutuhkan dana yang tidak sedikit dalam mengoperasionalkan segala aktivitas yang dilakukannya. Semakin banyak jumlah santri yang belajar di pesantren, semakin besar pula dana yang dibutuhkan oleh pengelola dalam melancarkan aktivitas pesantren, terutama hal-hal yang berkaitan dengan kelancaran proses belajar mengajar. Karena itulah secara otomatis pengurus juga akan melakukan proses pencatatan atas keuangan pondok pesantren, dengan tujuan untuk memudahkan pengelolaan dana yang ada (Fordebi \& Adesy, 2016: 125).

\subsection{Kebijakan Akuntansi Organisasi Nirlaba}

Karakteristik entitas nirlaba berbeda dengan entitas bisnis. Perbedaan utama terletak pada cara entitas nirlaba mendapatkan sumber daya yang dibutuhkan untuk melakukan berbagai aktivitas operasinya. Entitas nirlaba memperoleh sumber daya dari pemberi sumber daya yang tidak mengharapkan pembayaran kembali atau manfaat ekonomik yang sebanding dengan jumlah sumber daya yang diberikan. Akibatnya dalam entitas nirlaba timbul transaksi tertentu yang jarang dan bahkan tidak pernah terjadi dalam entitas bisnis, misalnya penerimaan sumbangan. Namun demikian dalam praktik entitas nirlaba sering tampil dalam berbagai bentuk, sehingga sering kali sulit dibedakan dengan entitas bisnis pada umumnya.

Kemampuan entitas nirlaba untuk dapat memberikan jasa dikomunikasikan melalui laporan posisi keuangan yang menyediakan informasi tentang aset, liabilitas, aset neto, serta informasi mengenai hubungan di antara unsur-unsur tersebut. Laporan ini menyajikan secara terpisah aset neto baik yang terikat maupun yang tidak terikat penggunaannya. Pertanggungjawaban manajer mengenai kemampuannya mengelola sumber daya entitas nirlaba yang diterima dari para pemberi sumber daya yang tidak mengharapkan pembayaran kembali disajikan melalui laporan aktivitas dan laporan arus kas. Laporan aktivitas menyajikan informasi mengenai perubahan yang terjadi dalam kelompok aset neto (IAI, 2016). 


\subsubsection{PSAK 45: Pelaporan Keuangan Entitas Nirlaba}

Sesuai dengan yang tercantum pada PSAK 45, tujuan dari pernyataan ini adalah untuk mengatur pelaporan keuangan entitas nirlaba. Dengan adanya pedoman pelaporan, diharapkan laporan keuangan entitas nirlaba dapat lebih mudah dipahami, memiliki relevansi, dan memiliki daya banding yang tinggi. Pernyataan ini berlaku bagi laporan keuangan yang disajikan oleh entitas nirlaba yang telah memenuhi karakteristik sebagai berikut:

a. Sumber daya entitas nirlaba berasal dari pemberi sumber daya yang tidak mengharapkan pembayaran kembali atau manfaat ekonomik yang sebanding dengan jumlah sumber daya yang diberikan.

b. Menghasilkan barang dan / atau jasa tanpa bertujuan mendapatkan laba, dan jika entitas nirlaba menghasilkan laba, maka jumlahnya tidak dibagikan kepada pendiri atau pemilik entitas nirlaba tersebut.

c. Tidak ada kepemilikan seperti umumnya pada entitas bisnis, dalam arti bahwa kepemilikan dalam entitas nirlaba tidak dapat dijual, dialihkan, atau ditebus kembali, atau kepemilikan tersebut tidak mencerminkan proporsi pembagian sumber daya dari entitas nirlaba pada saat likuidasi atau pembubaran entitas nirlaba.

Menurut PSAK 45 paragraf 03, Laporan keuangan untuk entitas nirlaba terdiri dari laporan posisi keuangan, laporan aktivitas, laporan arus kas, dan catatan atas laporan keuangan. Laporan keuangan tersebut berbeda dengan laporan keuangan untuk entitas bisnis pada umumnya.

Tujuan utama laporan keuangan adalah menyediakan informasi yang relevan untuk memenuhi kepentingan pemberi sumber daya yang tidak mengharapkan pembayaran kembali, anggota, kreditur, dan pihak yang lain yang menyediakan sumber daya bagi entitas nirlaba (IAI, 2016).

Secara rinci, tujuan laporan keuangan, yaitu untuk menyajikan informasi mengenai:

a. Jumlah dan sifat aset, liabilitas, dan aset neto entitas nirlaba;

b. Pengaruh transaksi dan peristiwa lain yang mengubah nilai dan sifat neto;

c. Jenis dan jumlah arus masuk dan arus keluar sumber daya dalam satu periode dan hubungan antar keduanya;

d. Cara entitas nirlaba mendapatkan dan membelanjakan kas, mendapatkan pinjaman dan melunasi pinjaman, serta faktor lain yang berpengaruh terhadap likuiditasnya;

e. Usaha jasa entitas nirlaba.

Laporan keuangan entitas nirlaba meliputi laporan posisi keuangan pada akhir periode laporan, laporan aktivitas dan laporan arus kas untuk suatu periode pelaporan, dan catatan atas laporan keuangan. Menurut IAI (PSAK 45, Par 10), Tujuan laporan posisi keuangan adalah untuk menyediakan informasi mengenai aset, liabilitas, dan aset neto serta informasi mengenai hubungan di antara unsur-unsur tersebut pada waktu tertentu. Laporan posisi keuangan mencakup entitas nirlaba secara keseluruhan dan menyajikan total aset, liabilitas, dan aset neto.

Tujuan utama laporan aktivitas yaitu untuk menyediakan informasi mengenai pengaruh transaksi dan peristiwa lain yang mengubah jumlah dan sifat neto; hubungan antar transaksi dan peristiwa lain; dan bagaimana penggunaan sumber daya dalam pelaksanaan berbagai program atau jasa. Informasi dalam laporan aktivitas, yang digunakan bersama dengan pengungkapan informasi dalam laporan keuangan lainnya, dapat membantu pemberi sumber daya yang tidak mengharapkan pembayaran kembali, anggota, kreditur, dan pihak lain untuk mengevaluasi kinerja dalam suatu periode; menilai upaya, kemampuan, dan berkesinambungan entitas nirlaba dan memberikan jasa; dan menilai pelaksanaan tanggung jawab dan kinerja manajer. Laporan aktivitas mencakup entitas nirlaba secara keseluruhan dan menyajikan perubahan jumlah aset neto selama suatu periode. Perubahan aset neto dalam laporan aktivitas tercermin pada aset neto atau ekuitas dalam posisi keuangan (IAI, 2016). 
Sesuai dengan PSAK 45, paragraf 33 dan 34 tertulis bahwa Tujuan utama laporan arus kas adalah menyajikan informasi mengenai penerimaan dan pengeluaran kas dalam suatu periode. Laporan arus kas disajikan sesuai PSAK 2 tentang Laporan Arus Kas atau SAK ETAP Bab 7 dengan tambahan berikut ini:

a. Aktivitas pendanaan:

1) Penerimaan kas dari pemberi sumber daya yang tidak mengharapkan pembayaran kembali yang penggunaannya dibatasi dalam jangka panjang,

2) Penerimaan kas dari pemberi sumber daya serta penghasilan investasi yang penggunaannya dibatasi untuk pemerolehan, pembangunan dan pemeliharaan aset tetap, atau peningkatan dana abadi,

3) Bunga dan dividen yang dibatasi penggunaannya dalam jangka panjang.

b. Pengungkapan informasi mengenai aktivitas investasi dan pendanaan nonkas, misalnya sumbangan berupa bangunan dan aset investasi.

\subsection{Kebijakan Akuntansi Syariah}

Aktivitas ekonomi berbasis syariah di Indonesia yang dinamis saat ini, khususnya keuangan syariah, memerlukan dukungan infrastruktur seperti fatwa syariah, regulasi, dan standar akuntansi keuangan yang mencerminkan esensi aktivitas tersebut. Ekonomi berbasis syariah dengan karakteristik yang khas bisa menjadi alternatif sistem perekonomian di tengah beragam aliran ekonomi di dunia (Mardiasmo, 2016)

Standar Akuntansi Syariah (SAS) adalah Pernyataan Standar Akuntansi Keuangan (PSAK) Syariah yang ditujukan untuk entitas yang melakukan transaksi syariah baik entitas lembaga syariah maupun lembaga non syariah. Pengembangan SAS dilakukan dengan mengikuti model SAK umum namun berbasis syariah dengan mengacu kepada fatwa MUI. Penyusunan standar akuntansi keuangan syariah dilakukan sesuai dengan perkembangan fatwa Dewan Syariah Nasional - Majelis Ulama Indonesia (DSN MUI) dan dengan mempertimbangkan dinamika aktivitas ekonomi berbasis syariah, terutama aktivitas bisnis keuangan syariah.

Standar akuntansi keuangan syariah mengatur transaksi berbasis syariah yang belum diakomodasi dalam standar akuntansi keuangan umum. Standar akuntansi keuangan syariah melengkapi standar akuntansi keuangan umum dengan mengatur akuntansi untuk transaksi syariah. Standar akuntansi keuangan syariah berbasis pada konsep-konsep akuntansi umum yang telah disesuaikan dengan prinsip-prinsip syariah. Hal yang diatur dalam standar akuntansi keuangan syariah adalah transaksi-transaksi syariah dan berlaku untuk para pihak yang melakukan transaksi tersebut. Saat ini transaksi syariah yang utama telah diatur dalam standar akuntansi keuangan syariah, seperti murabahah, istishna', salam, mudharabah, musyarakah, ijarah, tabarru', sukuk, dan zakat (Wibisana, 2016).

\section{1) PSAK 101: Penyajian Laporan Keuangan Syariah}

Tujuan dari PSAK 101 adalah untuk menetapkan dasar penyajian laporan keuangan bertujuan umum untuk entitas syariah yang selanjutnya disebut "laporan keuangan" supaya dapat dibandingkan baik dengan laporan keuangan periode sebelumnya maupun dengan laporan keuangan entitas syariah lain. Pernyataan ini mengatur persyaratan penyajian laporan keuangan, struktur laporan keuangan, dan persyaratan minimal isi laporan keuangan.

Menurut PSAK 101 paragraf 09, Laporan keuangan adalah suatu penyajian terstruktur dari posisi keuangan dan kinerja keuangan suatu entitas syariah. Tujuan laporan keuangan adalah untuk memberikan informasi mengenai posisi keuangan, kinerja keuangan, dan arus kas entitas syariah yang bermanfaat bagi sebagian besar penggunaan laporan keuangan dalam membuat keputusan ekonomik. Laporan keuangan juga menunjukkan hasil pertanggungjawaban manajemen atas penggunaan sumber daya yang dipercayakan kepada mereka. Dalam rangka mencapai tujuan tersebut, laporan keuangan menyajikan informasi mengenai entitas syariah yang meliputi: 
a. Aset;

b. Liabilitas;

c. Dana syirkah temporer;

d. Ekuitas;

e. Pendapatan dan beban termasuk keuntungan dan kerugian;

f. Kontribusi dari dan distribusi kepada pemilik dalam kapasitasnya sebagai pemilik;

g. Arus kas;

h. Dana zakat; dan

i. Dana kebajikan.

Informasi tersebut, beserta informasi lain yang terdapat dalam catatan atas laporan keuangan, membantu pengguna laporan keuangan dalam memprediksi arus kas masa depan dan, khususnya, dalam hal waktu dan kepastian diperolehnya kas dan setara kas.

Komponen laporan keuangan sesuai dengan PSAK 101 paragraf 10 terdiri dari komponen berikut ini:

a. Laporan posisi keuangan pada akhir periode;

b. Laporan laba rugi dan penghasilan komprehensif lain selama periode;

c. Laporan perubahan ekuitas selama periode;

d. Laporan arus kas selama periode;

e. Laporan sumber dan penyaluran dana zakat selama periode;

f. Laporan sumber dan penggunaan dana kebajikan selama periode;

g. Catatan atas laporan keuangan, berisi ringkasan kebijakan akuntansi penting dan informasi penjelasan lain; dan

h. Informasi komparatif mengenai periode sebelumnya sebagaimana ditentukan dalam paragraf 37 dan 38; dan

i. Laporan posisi keuangan pada awal periode terdekat sebelumnya yang disajikan ketika entitas syariah menerapkan suatu kebijakan akuntansi secara retrospektif atau membuat penyajian kembali pos laporan keuangan, atau ketika entitas syariah mereklasifikasi pos dalam laporan keuangannya.

Dalam paragraf 14 PSAK 101, tertulis bahwa "Jika entitas syariah belum melaksanakan fungsi sosial secara penuh, maka entitas syariah tetap menyajikan komponen laporan keuangan di paragraf 10 (e) dan (f)". Paragraf tersebut dicetak dengan huruf tebal dan miring yang artinya adalah mengatur prinsip-prinsip utama. Paragraf 10 (e) dan (f) merupakan komponen utama yang harus ada dalam laporan keuangan syariah, yaitu laporan sumber dan penyaluran dana zakat dan laporan sumber dan penggunaan dana kebajikan.

\section{2) Laporan Sumber dan Penyaluran Dana Zakat}

Pada PSAK 101 paragraf 119 menjelaskan bahwa, zakat adalah sebagian dari harta yang wajib dikeluarkan oleh wajib zakat (muzakki) untuk diserahkan kepada penerima zakat (mustahiq). Pembayaran zakat dilakukan jika nisab dan haulnya terpenuhi dari harta yang memenuhi kriteria wajib zakat.

Komponen dasar laporan sumber dan penyaluran dana zakat meliputi sumber dana, penggunaan dana selama suatu periode, serta saldo dana zakat yang menunjukkan dana zakat yang belum disalurkan pada tanggal tertentu (PSAK 101, par 120). Dana zakat tidak diperkenankan untuk menutup penyisihan kerugian aset produktif.

\section{3) Laporan Sumber dan Penggunaan Dana Kebajikan}

Menurut paragraf 124 pada PSAK 101, Komponen dasar laporan sumber dan pengg unaan dana kebajikan meliputi sumber dan penggunaan dana selama periode tertentu, serta saldo dana kebajikan yang menunjukkan dana kebajikan yang belum disalurkan pada tanggal tertentu.

Penerimaan dana kebajikan oleh entitas syariah diakui sebagai liabilitas paling likuid dan diakui sebagai pengurang liabilitas ketika disalurkan (PSAK 101, par 125). 
Dalam paragraf 123 PSAK 101 dijelaskan bahwa, Entitas syariah menyajikan laporan sumber dan penggunaan dana kebajikan sebagai komponen utama laporan keuangan, yang menunjukkan:

a. Sumber dana kebajikan berasal dari penerimaan:

1) Infaq;

2) Sedekah

3) Hasil pengelolaan wakaf sesuai dengan perundang-undangan yang berlaku;

4) Pengembalian dana kebajikan produktif;

5) Denda; dan

6) Penerimaan nonhalal.

b. Penggunaan dana kebajikan untuk:

1) Dana kebajikan produktif;

2) Sumbangan; dan

3) Penggunaan lain untuk kepentingan umum.

c. Kenaikan atau penurunan sumber dana kebajikan;

d. Saldo awal dana kebajikan;

e. Saldo akhir dana kebajikan.

\section{METODE PENELITIAN}

3.1. Jenis dan Sumber Data

Dalam penelitian ini, penulis menggunakan jenis data kualitatif. Jenis data kualitatif merupakan data yang disajikan secara deksriptif atau berbentuk uraian, dalam hal ini yaitu uraian laporan keuangan serta laporan dana zakat dan kebajikan dalam kurun waktu 3 tahun terakhir. Sumber data yang digunakan dalam penelitian ini adalah data primer dan data sekunder.

\subsection{Teknik Pengumpulan Data}

Teknik yang penulis pakai dalam pengumpulan data adalah Dokumentasi, Observasi, Wawancara, dan Studi Kepustakaan.

\subsection{Metode Analisis Data}

Metode analisis yang digunakan dalam penelitian ini adalah metode analisis deksriptif. Metode analisis ini dimulai dengan langkah mengumpulkan dan menyaring keterangan-keterangan yang diperoleh secara menyeluruh dan detail, kemudian diuraikan sehingga diperoleh gambaran yang jelas.

\section{HASIL PENELITIAN DAN PEMBAHASAN}

\subsection{Hasil Penelitian}

\section{1) Pencatatan Keuangan Pondok Pesantren As-Salam}

Pencatatan keuangan yang dilakukan pondok pesantren merupakan pencatatan yang sederhana. Dalam mencatat aktivitas keuangan, pondok pesantren hanya mencatatnya pada buku yang sudah disediakan (buku kas) dimana buku tersebut mencatat seluruh transaksi yang dilakukan Pondok pesantren, yaitu pemasukan dan pengeluaran. Pencatatan keuangan dalam pondok pesantren dilakukan oleh bendahara serta para stafnya. Pencatatan tersebut masih sangat sederhana tanpa dilakukan perhitungan akhir untuk menyesuaian bagian debit dan kreditnya. Sesuai dengan 3 transaksi yang diuji setiap tahun, dalam pengakuannya, pondok pesantren mengakui transaksi yang terjadi sesuai tanggal terjadinya transaksi tersebut, namun pondok pesantren tidak memiliki akun-akun tertentu dalam mengakui transaksi yang terjadi, karena pengakuannya hanya sebatas penerimaan dan pengeluaran yang dilakukan. Sedangkan untuk pengukurannya, sering terdapat banyak kesalahan sehingga jumlah transaksi pun terkadang tidak jelas dan tidak sesuai dengan pengakuan transaksi yang ditulis. 
Pencatatan keuangan pondok pesantren berdasarkan penerimaan dan pengeluaran. Dimana penerimaan meliputi:
a. Pembayaran SPP santri
b. Unit usaha berupa Jasa Lundry, kantin dan Pulsa
c. Dana Sosial dari pegawai dan karyawan
d. Pengembalian Pinjaman
e. Penerimaan Santri Baru
f. Infaq, Sumbangan/sedekah, Wakaf

Selain dari penerimaan yang sudah disebutkan, masih ada pula penerimaan yang sifatnya sementara yaitu Bantuan Siswa Miskin (BSM) yang nantinya akan diberikan kepada para santri yang tidak mampu. Adapun Pengeluaran yang sering dicatat Pondok pesantren berupa kebutuhan-kebutuhan Pondok pesantren tersebut misalnya untuk pemeliharaan saranaprasarana, pembayaran listrik, pembayaran gaji, konsumsi, serta pemberian dana sosial.

\section{2) Penyajian Laporan Keuangan Pondok Pesantren As-Salam}

Penyajian laporan keuangan pondok pesantren disajikan dengan cara mencatat seluruh penerimaan dan pengeluaran selama periode. Untuk Penyajian Laporan keuangan, pondok pesantren hanya menyajikannya selama per bulan dan tidak menyajikan laporan tahunan. Laporan keuangan dibuat oleh bendahara dan stafnya yang nantinya akan ditandatangani oleh pimpinan pondok pesantren. Penyajian tidak mengacu pada peraturan manapun, sehingga informasi yang didapatkan dari laporan keuangan masih kurang jelas. Hal ini karena laporan keuangan per bulan yang disajikan masih sangat sederhana.

Laporan keuangan disajikan berdasarkan pencatatan pada buku kas harian yang menggambarkan penerimaan serta pengeluaran yang dilakukan oleh Pondok pesantren yang ditandatangani oleh pengelola keuangan serta pimpinan pondok pesantren. Laporan keuangan yang disajikan merupakan hasil rekapitulasi dari buku kas harian yang dicatat setiap adanya transaksi. Karena ketidaksesuaian pencatatan terhadap pengukuran dan pengakuannya, maka laporan yang disajikan pun masih kurang jelas dengan nilai yang berbeda. Hal ini dikarenakan kurang telitinya staf penanggungjawab dalam pengakuan dan pengukuran sehingga menyebabkan penyajian laporan keuangan yang juga tidak jelas.

Sesuai dengan data yang didapat, pondok pesantren hanya mencatat aset lancar berupa uang yang diterima maupun dikeluarkan oleh pondok pesantren tersebut. Sedangkan untuk aset tidak lancar, tidak dicantumkan dalam laporan keuangan. Aset tidak lancar hanya dicatat kepemilikannya oleh bagian sarana-prasarana, namun pondok pesantren tidak mencatat penyusutan dari aset tidak lancar. Hal ini karena laporan keuangan hanya mencatat penerimaan dan pengeluaran bulanan, sehingga tidak ada informasi yang lebih jelas mengenai aset tidak lancar yang seharusnya diakui dan disusutkan per tahun. Laporan keuangan pondok pesantren dapat dilihat pada lampiran di bagian akhir skripsi.

\section{3) Pengungkapan Laporan Keuangan Pondok Pesantren As-Salam}

Pengungkapan, dalam hal ini adalah Catatan Atas Laporan Keuangan yang biasanya tercantum dalam laporan keuangan entitas, tidak terdapat dalam laporan keuangan yang disajikan oleh pondok pesantren. Menurut Bendahara dan staf bendahara pondok pesantren, semua informasi keuangan sudah dicatat dalam laporan keuangan bulanan. Sedangkan untuk acuan peraturan, pondok pesantren tidak memiliki peraturan khusus yang harus diikuti. Laporan keuangan hanya dibuat secara sederhana yang dimengerti oleh Bendahara, staf bendahara, serta pimpinan pondok pesantren.

\section{4) Penyajian Laporan Dana Zakat \& Dana Kebajikan Pondok Pesantren As-Salam}

Untuk pencatatan, penyajian dan pengungkapan laporan dana zakat dan dana kebajikan, pondok pesantren hanya mencatatnya secara sederhana pula, dimana pencatatan dilakukan secara langsung dalam laporan keuangan bulanan. Misalnya, jika bulan puasa (bulan ramadhan) jatuh pada bulan juli, maka zakat dicatat dalam laporan keuangan bulan juli 
tersebut. Zakat dalam laporan keuangan, diakui sebagai infaq oleh pondok pesantren sehingga tidak terdapat adanya pengakuan dana zakat dalam pondok pesantren. Hal ini dikarenakan pondok pesantren bukanlah suatu organisasi yang betujuan untuk mendapatkan laba atau keuntungan, sehingga tidak ada kewajiban bagi pondok pesantren dalam menerima serta mengeluarkan dana zakat.

Sesuai dengan data yang didapatkan, dana zakat dan kebajikan hanya dicatat pemasukannya, namum penggunaannya tidak dicatat secara khusus, sehingga masuk sebagai kas pondok pesantren dan penggunaannya digunakan untuk kepentingan umum pondok pesantren.

\subsection{Pembahasan}

\section{1) Analisis Pencatatan Laporan Keuangan Pondok Pesantren As-Salam}

Proses pencatatan transaksi keuangan yang dilakukan pondok pesantren tidak mengacu pada pedoman ataupun acuan tertentu. Berdasarkan peraturan PSAK yang berlaku, Pencatatan keuangan yang harus dilihat adalah pengakuan dan pengukuran. Pengakuan harus berdasarkan tanggal transaksi sedangkan pengukuran dilihat dari seberapa banyak dana yang diterima maupun dikeluarkan.

Dalam pengakuannya, pondok pesantren tidak memisahkan akun-akun yang seharusnya dipisahkan, karena sistem keuangan pondok pesantren hanya merupakan pencatatan dari penerimaan serta pengeluaran yang dilakukan. contohnya dapat dilihat dari transaksi yang dilakukan pondok pesantren dimana pinjaman yang diberikan pondok pesantren kepada karyawan ditulis sebagai pengeluaran dan tidak diakui sebagai piutang sehingga tidak tercatat secara rinci seberapa banyak piutang yang dimiliki pondok pesantren. Hal ini mengakibatkan laporan keuangan menjadi tidak relevan. Seharusnya, pondok pesantren mengakui adanya piutang sehingga tidak terjadi kesalahan dalam menghitung jumlah aset.

Sedangkan untuk pengukuran, laporan keuangan seharusnya dicatat berdasarkan pengakuan yang terjadi. Dalam pengukurannya, masih terdapat banyak kekeliruan, seperti kesalahan dalam penjumlahan yang dilakukan, misalnya dalam transaksi penerimaan kas pembayaran SPP santri dimana penjumlahannya hampir setiap bulan mengalami kekeliruan sehingga tidak menghasilkan informasi keuangan yang andal. Jika terus menerus terjadi kesalahan penjumlahan, maka akan terjadi kesalahan informasi pula pada laporan keuangan. Terjadinya kesalahan atau kekeliruan dalam menyusun laporan keuangan pondok pesantren disebabkan oleh kurangnya pengetahuan dari pengelola keuangan pondok pesantren. Selain itu, pondok pesantren juga tidak memiliki pedoman atau kebijakan tertentu yang digunakan sebagai acuan dalam pembuatan laporan keuangan. Untuk itu, pembuatan laporan keuangan hanya sebatas pencatatan penerimaan dan pengeluaran yang belum sepenuhnya benar. Agar laporan keuangan yayasan memadai, maka sebaiknya yayasan membuat suatu pedoman akuntansi dalam penyusunan penyajian laporan keuangan yang didalamnya berisi standar akuntansi keuangan yang berlaku umum untuk mengatasi kesalahan dalam penyusunan laporan keuangan.

Berdasarkan kaidah PSAK 45 tentang pelaporan keuangan entitas nirlaba, seharusnya laporan keuangan dihitung secara teliti dan hati-hati agar tidak terjadi kesalahan dalam penyajian informasi keuangan pondok pesantren. Selain itu, terdapat akun-akun yang harus dipisahkan seperti piutang dan kewajiban. Dengan adanya pemisahan akun, maka akan lebih mudah untuk memahami isi informasi dari laporan keuangan karena sudah jelas tertulis jumlah aset serta kewajiban yang dikeluarkan selama setahun.

\section{2) Analisis Penyajian Laporan Keuangan Pondok Pesantren As-Salam}

Dalam Penyajian laporan keuangan, pondok pesantren menyajikannya berdasarkan hasil rekapitulasi pencatatan transaksi harian yang terjadi dalam pondok pesantren. Penyajian laporan keuangan yang dilakukan pun hanya laporan keuangan bulanan dan tidak terdapat 
laporan keuangan tahunan. Akibat pengakuan dan pengukuran yang dilakukan pondok pesantren masih terdapat banyak kekeliruan seperti yang sudah dijelaskan, maka penyajian laporan keuangan yang disajikan pun masih belum andal sehingga menghasilkan informasi yang kurang memadai. Kekeliruan yang sering terjadi dalam penyajian laporan keuangan pondok pesantren berupa kesalahan penjumlahan serta format penyajian laporan keuangan.

Berdasarkan peraturan PSAK 45, laporan keuangan entitas nirlaba seharusnya disajikan per tahun. Selain itu, penyajian laporan keuangan juga harus dibuat lebih rinci dan jelas, terlebih dalam perhitungannya. Dalam penyajian laporan keuangan entitas nirlaba, terdapat 4 laporan yang seharusnya dibuat pondok pesantren untuk menghasilkan informasi yang andal. Selain itu, dengan mengikuti pedoman PSAK yang berlaku, diharapkan laporan keuangan pondok pesantren dapat lebih mudah dipahami, memiliki relevansi, serta memiliki daya banding yang tinggi.

Berdasarkan pada transaksi yang terjadi selama tahun 2014, 2015, dan 2016, maka penulis akan membuat laporan keuangan yang sesuai dengan PSAK 45. Beberapa Tabel berikut dapat dilihat laporan posisi keuangan, Laporan Aktivitas, Laporan Arus Kas, serta Catatan Atas Laporan Keuangan Pondok Pesantren As-Salam.

Tabel A

Laporan Posisi Keuangan

Pondok Pesantren As-Salam

Laporan Posisi Keuangan

Per 31 Desember 2014, 2015, 2016

(dalam jutaan rupiah)

ASET

Aset Lancar

Kas dan Setara Kas

$\underline{2014} \underline{2015} \underline{2016}$

Aset Tidak Lancar

Jumlah Aset

LIABILITAS

Liabilitas Jangka Pendek

Liabilitas Jangka Panjang

Jumlah Liabilitas

ASET NETO

Tidak terikat (catatan B)

Terikat temporer (catatan B)

Terikat Permanen

Jumlah Aset Neto

Jumlah Liabilitas dan Aset Neto

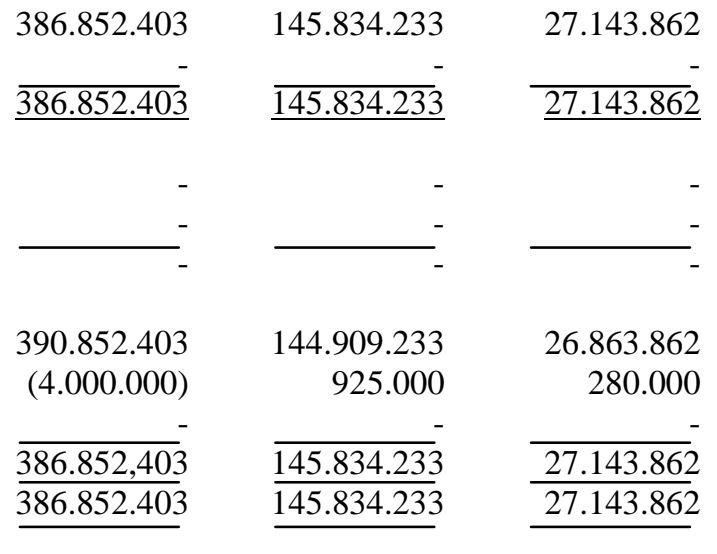

Sumber: Data Olahan Tahun 2014, 2015, dan 2016

Berdasarkan pada tabel A terdapat akun-akun yang akan dijelaskan sebagai berikut.

1. Aset

Kas dan setara kas yang disajikan dalam laporan posisi keuangan merupakan jumlah dari aset bersih pada setiap akhir tahun. Aset pondok pesantren hanya terdiri dari kas dan setara kas karena pondok pesantren tidak memiliki piutang dan persediaan, sedangkan untuk aset tetap dan perlengkapan tidak dicatat karena hanya dicatat sebagai inventaris sehingga tidak diketahui nilai buku dari aset tetap dan perlengkapan.

2. Liabilitas dan Aset Neto

Pondok pesantren tidak memiliki saldo kewajiban pada akhir tahun karena telah melunasi semua kewajibannya sebelum 31 Desember. Untuk aset bersih tidak terikat, merupakan hasil perhitungan jumlah pendapatan dan penghasilan tidak terikat dikurangi jumlah beban dan pengeluaran. Aset bersih terikat temporer adalah saldo akhir yang 
merupakan hasil dari perhitungan sumbangan terikat dikurangi dengan penggunaannya selama periode, perhitungannya disajikan dalam catatan atas laporan keuangan.

Tabel B

Laporan Aktivitas

Pondok Pesantren As-Salam

Laporan Aktivitas

Per 31 Desember 2014, 2015, 2016

(dalam jutaan rupiah)

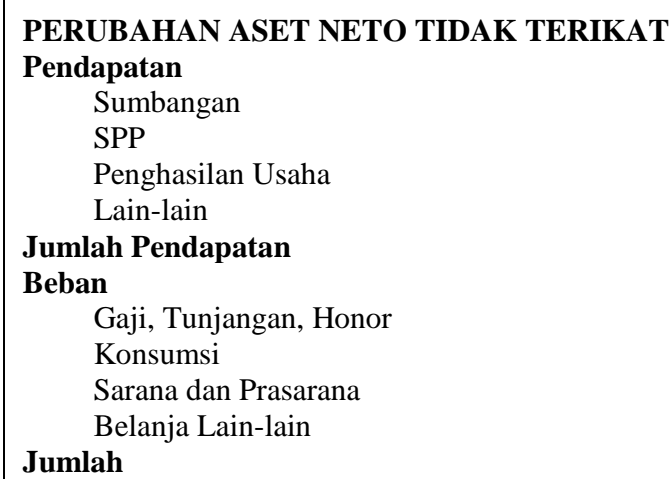

Kenaikan Aset Neto Tidak Terikat

\begin{tabular}{|c|c|c|}
\hline$\underline{2014}$ & $\underline{2015}$ & 2016 \\
\hline 28.241 .000 & 61.170 .500 & 2.074 .000 \\
\hline 1.392 .470 .000 & 1.311 .550 .000 & 1.296 .400 .000 \\
\hline 282.073 .180 & 246.147 .150 & 335.760 .700 \\
\hline 749.357 .643 & 413.946 .081 & 967.001 .800 \\
\hline 2.452.141.823 & $\overline{2.032 .813 .731}$ & $\underline{2.601 .236 .500}$ \\
\hline 666.353 .800 & 612.174 .000 & 683.455 .500 \\
\hline 567.148 .900 & 680.264 .478 & 752.357 .250 \\
\hline 310.649 .388 & 269.797.070 & 336.082 .888 \\
\hline 517.333 .482 & 326.042 .950 & 803.058 .500 \\
\hline 2.061 .485 .570 & $\underline{1.888 .278 .498}$ & 2.574 .954 .138 \\
\hline 390.656 .253 & 144.535 .233 & 26.282 .362 \\
\hline (4.000.000) & 925.000 & 280.000 \\
\hline$(4.000 .000)$ & 925.000 & 280.000 \\
\hline 386.656 .253 & 145.460 .233 & 26.562 .362 \\
\hline 196.150 & 374.000 & 581.500 \\
\hline 386.852 .403 & 145.834 .233 & 27.143 .862 \\
\hline
\end{tabular}

PERUBAHAN ASET NETO TERIKAT TEMPORER

Dana Sosial

Perubahan Aset Neto Terikat Temporer

KENAIKAN ASET NETO

ASET NETO AWAL TAHUN

ASET NETO AKHIR TAHUN

Sumber: Data Olahan Tahun 2014. 2015, 2016

Berikut adalah akun-akun yang dijelaskan berdasarkan Tabel B

1. Pendapatan

Dalam laporan pondok pesantren, akun Pendapatan terdiri dari Sumbangan, SPP yang dibayarkan santri setiap bulannya, Penghasilan usaha, dan Lain-lain. Nilai sumbangan merupakan total sumbangan yang diterima pondok pesantren. SPP merupakan jumlah SPP selama periode setahun yang diterima pondok pesantren. Penghasilan usaha adalah total dari usaha yang dilakukan pondok pesantren berupa kantin dan penjualan buku. Sedangkan pendapatan lain-lain merupakan total dari penerimaan lain-lain pondok pesantren.

2. Beban

Seluruh komponen yang termasuk dalam akun beban merupakan semua penggunaan dana yang dikeluarkan pondok pesantren untuk membiayai setiap program atau kegiatan yang dilaksanakan. 


\section{Tabel C}

Laporan Arus Kas

\begin{tabular}{|c|c|c|c|}
\hline $\begin{array}{r}\text { Pondok Pesa } \\
\text { Laporan } \\
\text { Per } 31 \text { Desembe } \\
\text { (dalam jut }\end{array}$ & $\begin{array}{l}\text { cen As-Salam } \\
\text { rus Kas } \\
014,2015,2016 \\
\text { an rupiah) }\end{array}$ & & \\
\hline & 2014 & 2015 & 2016 \\
\hline AKTIVITAS OPERASI & & & \\
\hline Kas dari Pendapatan & 1.674.543.180 & 1.557.697.150 & 1.632.160.700 \\
\hline Kas dari Pemberi Sumber Daya & 28.241 .000 & 61.170 .500 & 2.074 .000 \\
\hline Penerimaan lain-lain & 745.357 .643 & 414.871 .081 & 967.281 .800 \\
\hline & 2.448 .141 .823 & $\underline{2.033 .738 .731}$ & 2.601 .516 .500 \\
\hline Kas yang dibayarkan kepada karyawan & $(666.353 .800)$ & $\overline{(612.174 .000)}$ & $\overline{(683.455 .500)}$ \\
\hline Biaya lain-lain & $(517.333 .482)$ & $(326.042 .950)$ & $(803.058 .500)$ \\
\hline & $(1.183 .687 .282)$ & (938.216.950) & $\overline{(1.486 .514 .000})$ \\
\hline Kas neto yang diterima untuk aktivitas operaasi & 1.264.454.541 & 1.099.521.781 & 1.115.002.500 \\
\hline AKTIVITAS INVESTASI & & & \\
\hline Pembelian peralatan & $(310.649 .388)$ & $(269.797 .070)$ & $(336.082 .888)$ \\
\hline Kas neto yang digunakan untuk aktivitas investasi & $(310.649 .388)$ & $(269.797 .070)$ & $(336.082 .888)$ \\
\hline AKTIVITAS PENDANAAN & & & \\
\hline Pembayaran kewajiban tahunan & $(567.148 .900)$ & $(680.264 .478)$ & $(752.357 .250)$ \\
\hline Kas neto yang digunakan untuk aktivitas pendanaan & $(567.148 .900)$ & $(680.264 .478)$ & $(752.357 .250)$ \\
\hline KENAIKAN NETO DALAM KAS DAN SETARA & & & \\
\hline KAS & 386.656 .253 & 145.460 .233 & 26.562.362 \\
\hline KAS DAN SETARA KAS AWAL TAHUN & 196.150 & 374.000 & 581.500 \\
\hline KAS DAN SETARA KAS AKHIR TAHUN & 386.852 .403 & 145.834 .233 & 27.143 .862 \\
\hline
\end{tabular}

Sumber: Data Olahan Tahun 2014, 2015, 2016

Berikut adalah penjelasan sesuai dengan Tabel C

1. Arus Kas dari Aktivitas Operasi

Komponen yang disajikan dalam aktivitas operasi merupakan penambahan dan pengurangan arus kas yang terjadi terkait dengan aktivitas operasional dari pondok pesantren

2. Arus Kas dari Aktivitas Investasi

Yang termasuk dalam arus kas ini adalah semua penerimaan dan pengeluaran pondok pesantren yang terkait dengan investasi pondok pesantren. Pada pondok pesantren hanya terjadi pengeluaran berupa pebelian peralatan.

3. Arus Kas dari Aktivitas Pendanaan

Komponen yang termasuk dalam aktivitas pendanaan adalah pembayaran kewajiban tahunan. 


\section{Tabel D}

Catatan Atas Laporan Keuangan

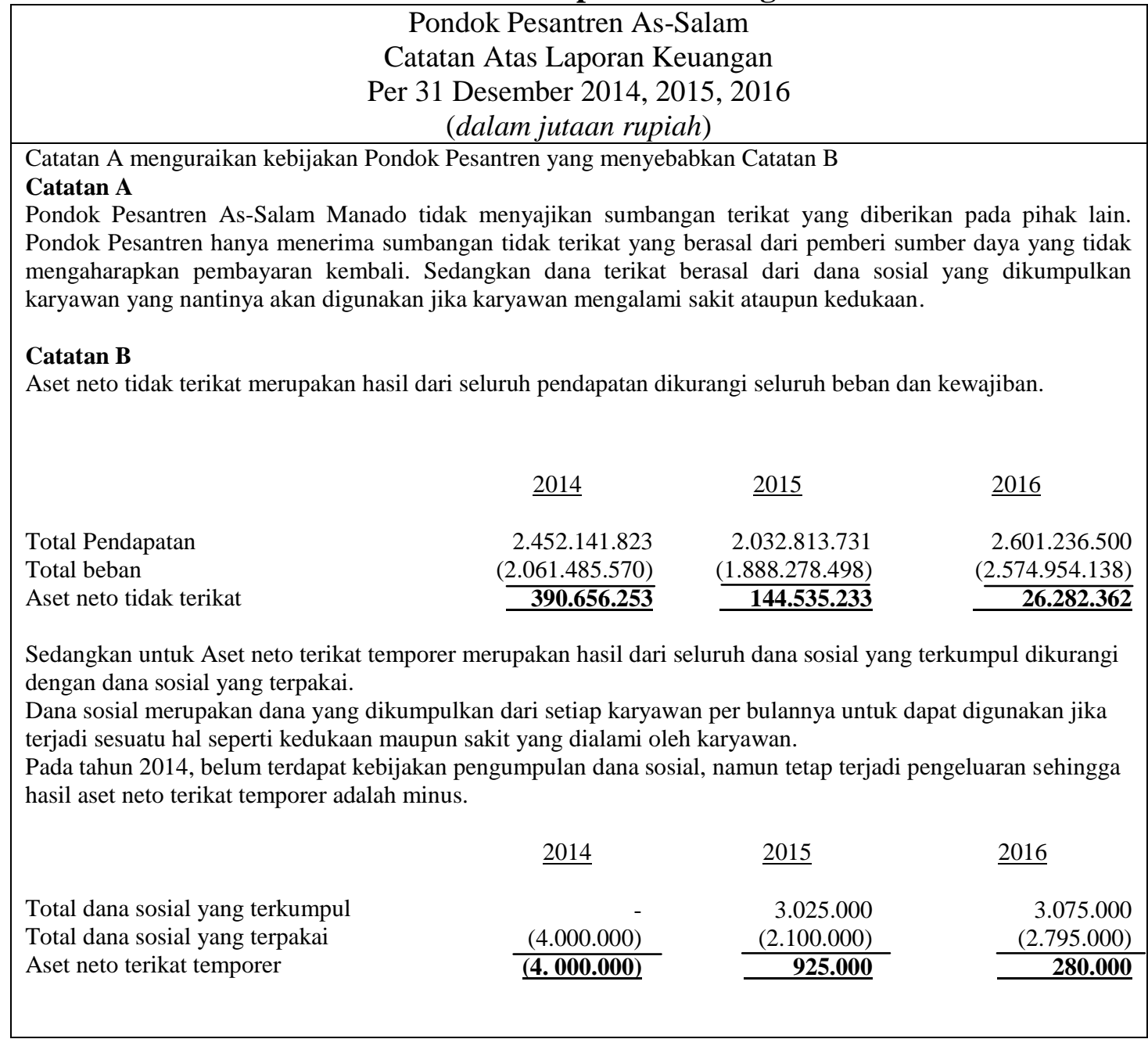

Sumber: Data Olahan Tahun 2014, 2015, 2016

\section{3) Analisis Pengungkapan Laporan Keuangan Pondok Pesantren As-Salam}

Pengungkapan Laporan keuangan, dalam hal ini adalah Catatan Atas Laporan Keuangan serta kebijakan yang digunakan pondok pesantren dalam menyusun laporan keuangan. Pondok pesantren tidak memiliki catatan atas laporan keuangan sebagai penjelas dalam penyajian laporan keuangan. Sedangkan untuk kebijakan pondok pesantren dalam melakukan pencatatan, dan penyajian laporan keuangan, hanya berdasarkan pengetahuan yang dimiliki oleh bendahara dan staf bendaharanya. Karena minimya pengetahuan pengelola keuangan tentang akuntansi serta tidak adanya acuan pedoman yang diikuti, maka informasi keuangan menjadi tidak relevan. Pengungkapan yang seharusnya dilakukan pondok pesantren adalah berdasarkan PSAK 45 yang mengatur tentang pelaporan keuangan entitas nirlaba.

Berdasarkan laporan keuangan yang telah disesuaikan pada tabel D, maka didapat bahwa Catatan atas Laporan Keuangan Pondok Pesantren As-Salam Manado yaitu berupa:

1. Kebijakan Pondok Pesantren As-Salam Manado

2. Catatan aset bersih tidak terikat

3. Catatan aset bersih terikat temporer

4) Analisis Penyajian Laporan Dana Zakat dan Dana Kebajikan As-Salam berdasarkan PSAK 101

Laporan dana zakat harus disajikan untuk setiap entitas. Namun, untuk entitas yang tidak berorientasi pada laba (Nirlaba), tidak wajib menyajikan dana zakat, karena entitas 
tersebut tidak bertujuan untuk menghasilkan keuntungan. Sehingga yang harus disajikan oleh entitas nirlaba yang berhubungan dengan Laporan keuangan syariah adalah Laporan dana kebajikan, dimana dalam laporan tersebut akan diungkapkan sumber serta penggunaan dari dana kebajikan.

Pondok Pesantren tidak memberi ataupun menerima zakat atas nama pondok pesantren sendiri ataupun yayasan, karena tidak terdapat keuntungan yang sesuai dengan haul yang harusnya dikeluarkan sehingga zakat yang dilakukan oleh perangkat-perangkat yayasan ataupun pondok pesantren hanya merupakan zakat per orangan yang langsung disetor masing-masing kepada amil zakat. Untuk itu, Pondok pesantren dianjurkan membuat laporan dana kebajikan sebagaimana mestinya karena terdapat penerimaan dan pengeluaran yang dilakukan pondok pesantren terkait dengan dana kebajikan.

Berikut adalah Laporan dana kebajikan sebagaimana yang seharusnya disajikan oleh Pondok Pesantren As-Salam Manado

\section{Tabel E}

Laporan Sumber dan Penggunaan Dana Kebajikan

\begin{tabular}{|c|c|c|c|}
\hline \multicolumn{4}{|c|}{$\begin{array}{c}\text { Pondok pesantren As-Salam } \\
\text { Laporan Sumber dan Penggunaan Dana Kebajikan } \\
\text { Periode yang berakhir pada 31 Desember 2014, 2015, } 2016\end{array}$} \\
\hline & $\underline{2014}$ & $\underline{2015}$ & $\underline{2016}$ \\
\hline SUMBER DANA KEBAJIKAN & & & \\
\hline Infaq & 25.641 .000 & 13.070 .500 & 2.074 .000 \\
\hline Sedekah & 6.100 .000 & 3.100 .0000 & \\
\hline Wakaf & - & 45.000 .000 & \\
\hline Dana Sosial & - & 3.025 .000 & 3.075 .000 \\
\hline Jumlah & $\underline{31.741 .000}$ & $\underline{64.195 .500}$ & $\underline{5.149 .000}$ \\
\hline \multicolumn{4}{|l|}{ PENGGUNAAN DANA KEBAJIKAN } \\
\hline Dana Sosial & $(4.000 .000)$ & $(2.100 .000)$ & $(2.795 .000)$ \\
\hline $\begin{array}{l}\text { Penggunaan Lainnya untuk kepentingan } \\
\text { umum }\end{array}$ & $\underline{(27.241 .000)}$ & $\underline{(58.291 .200)}$ & $(1.984 .000)$ \\
\hline & 500.000 & 3.804 .300 & 370.000 \\
\hline KENAIKAN & 78.000 & 57.500 & 83.100 \\
\hline $\begin{array}{l}\text { SALDO AWAL } \\
\text { SALDO AKHIR }\end{array}$ & $\underline{578.000}$ & $\underline{3.861 .800}$ & $\underline{453.100}$ \\
\hline
\end{tabular}

Sumber: Data Olahan Tahun 2014, 2015, 2016

Penjelasan berdasarkan Tabel E adalah sebagai berikut

1. Sumber Dana Kebajikan

Komponen yang termasuk dalam sumber dana kebajikan adalah dana yang diterima oleh pondok pesantren berupa infaq, Sedekah (Sumbangan), Wakaf, serta Dana sosial.

2. Penggunaan Dana Kebajikan

Penggunaan dana kebajikan merupakan pengeluaran yang dilakukan terkait dengan dana kebajikan yang diterima seperti dana sosial dan penggunaan lain-lain untuk kepentingan umum pondok pesantren.

\section{KESIMPULAN DAN SARAN}

\subsection{Kesimpulan}

Berdasarkan hasil penelitian dan pembahasan mengenai Analisis Pelaporan Keuangan di Yayasan As-Salam Manado, maka diperoleh beberapa kesimpulan sebagai berikut:

1. Pencatatan transaksi keuangan yang dilakukan Yayasan As-Salam Manado belum memadai. Hal ini jika ditinjau dari sisi pengakuan dan pengukurannya masih terdapat banyak kekeliruan dan tidak sesuai dengan PSAK. 
2. Penyusunan Laporan Keuangan Yayasan As-Salam Manado, dalam hal ini adalah penyajian dan pengungkapannya belum sesuai dengan format laporan keuangan entitas nirlaba yang ada pada Pernyataan Standar Akuntansi Keuangan No. 45. Hal ini bisa langsung tercermin dari lembaga yang dimiliki oleh Yayasan.

3. Pelaporan dana kebajikan dari yayasan pun masih belum sesuai dengan format laporan dana kebajikan sebagaimana diatur dalam pernyataan Standar Akuntansi Keuangan No. 101 yang mengatur tentang Laporan Keuangan Syariah. Hal ini disebabkan oleh keterbatasan pengetahuan oleh pengelola tentang mengelola keuangan.

\subsection{Saran}

Berdasarkan kesimpulan yang sudah disebutkan dalam penelitian ini. Maka saran yang dapat diberikan penulis adalah sebagai berikut.

1. Dalam Penyusunan Laporan Keuangan, sebaiknya yayasan mengacu pada peraturan yang telah disahkan oleh Ikatan Akuntan Indonesia yakni PSAK No. 45 yang mengatur tentang Pelaporan Keuangan entitas nirlaba serta PSAK 101 yang mengatur tentang Pelaporan Keuangan Syariah, khususnya dalam komponen Laporan Sumber dan Penggunaan Dana kebajikan.

2. Sebaiknya, yayasan melakukan penilaian aset sehingga aset tidak lancar seperti aset tetap dan peralatan disajikan lengkap dengan nilai buku atau harga perolehannya.

3. Untuk pengelola keuangan yayasan, sebaiknya melakukan pelatihan mengenai Penyusunan laporan keungan sesuai dengan aturan yang diberlakukan oleh Ikatan Akuntan Indonesia, khususnya pada Penyusunan Laporan Keuangan entitas nirlaba dan Penyusunan Laporan keuangan Syariah.

4. Bagi Ikatan Akuntan Indonesia, sebaiknya mengadakan suatu kegiatan sosial yang bisa membantu Pengelola Keuangan entitas nirlaba dalam melakukan penyusunan laporan keuangan entitas, misalnya sosialisasi ataupun membagikan pedoman peraturan akuntansi keuangan pada entitas nirlaba yang ada di Indonesia.

\section{DAFTAR PUSTAKA}

Akbar, Farhan Satria. 2017. 4 Pilar Standar Akuntansi Keuangan. www.scdc.binus.ac.id. Diakses pada 12 Januari 2018.

Badiah, Siti. 2015. Analisis Penerapan Pencatatan Keuangan Berbasis PSAK Syariah No. 101 (Studi Interpretif pada Yayasan Yatim Piatu Singaraja). Singaraja: Universitas Pendidikan Ganesha. Jurnal Universitas Pendidikan Ganesha Vol. 3, No. 1.

Fordebi dan Adesy. Akuntansi Syariah. 2016. Jakarta: DPN FORDEBI dan ADESY.

Giri, Efraim Ferdinan. Akuntansi Keuangan Menengah 1. 2017. Edisi kedua. Yogyakarta: UPP STIM YKPN.

Harahap, Sofyan Syafri. Analisis Kritis atas Laporan Keuangan. 2015. Jakarta: Rajagrafindo Persada

Ifhana, Ahmad. 2010. Laporan Sumber dan Penggunaan Dana Zakat. www.sharianomics.wordpress.com. Diakses pada 10 Januari 2018.

Ikatan Akuntan Indonesia (IAI). 2016. Standar Akuntansi Keuangan Syariah. Jakarta: IAI.

Ikatan Akuntan Indonesia (IAI). 2016. Standar Akuntansi Keuangan. Jakarta: IAI

Irton. Handbook of Accounting. 2010. Edisi kedua. Yogyakarta: UPP STIM YKPN.

Ikhsan, Amrul. 2017. Penerapan Standar Akuntansi Keuangan Syariah pada Koperasi Jasa

Keuangan Syariah (Studi pada Baitul Qiradh di Kota Banda Aceh). Banda Aceh:

Universitas Syiah Kuala. Jurnal Ilmiah Mahasiswa Ekonomi Akuntansi Vol. 2, No.

3, Hal. 100-110. ISSN 2581-1002. 
Kholifah, Alif. 2015. Dana Kebajikan. Penyajian Laporan Sumber dan Penggunaan Dana Kebajikan KJKS BMT Mandiri Sejahtera Gresik berdasarkan PSAK No. 101. Surabaya: Universitas Islam Negeri Sunan Ampel. Jurnal Akuntansi Integratif Vol. 1, No. 1.

Kiamuddin. 2017. Transaksi Dana Zakat dan Dana Kebajikan. www.eilmuekonomi.blogspot.co.id. Diakses pada 11 Januari 2018.

Mardiasmo dan Wibisana. Standar Akuntansi Keuangan Syariah. 2016. Jakarta: IAI.

Mulyadi. Sistem Akuntansi. 2014. Edisi ketiga. Universitas Gadjah Mada: Salemba Empat.

Nurhayati, Sri dan Wasilah. Akuntansi Syariah di Indonesia. 2016. Edisi keempat. Jakarta: Salemba Empat.

Putri, Netthie Mentari. 2017. Organisasi Nirlaba. www.socidoc.com. Diakses pada 21 Februari 2018

Rahayu, Srikandi. 2017. Pengertian Organisasi Nirlaba serta Karakteristiknya. www.seputarpengertian.blogspot.co.id. Diakses pada 21 Februari 2018.

Rezita, Reza. 2017. Penerapan PSAK Nomor 101 pada BMT Sakinah Masjid Baburrahim Nagari Batubasa Kecamatan Pariangan. Batusangkar: Institut Agama Islam Negeri Batusangkar.

Rickiany, Liza. 2010. Penerapan PSAK No. 101 atas Transaksi Ijarah pada PT. BNI Syariah Cabang Medan. Medan: Universitas Sumatera Utara.

Sodikin, Slamet Sugiri dan Riyono, Bogat Agus. Akuntansi Pengantar 1. 2015. Yogyakarta: UPP STIM YKPN.

Sujarweni, V. Wiratna. Sistem Akuntansi. 2015. Bandung: Pustaka Baru Press.

Tinungki, Angelia Novrina Meilani. 2014. Penerapan Laporan Keuangan Organisasi Nirlaba Berdasarkan PSAK No.45 pada Panti Sosial Tresna Werdhana. Manado: Universitas Sam Ratulangi. Jurnal EMBA Vol. 2, No. 2 Hal 808-819. ISSN 2303-1174.

Ulfa, Mei Witria. 2014. Analisis Penerapan Pernyataan Standar Akuntansi Keuangan (PSAK) No. 45 Tentang Pelaporan Keuangan Organisasi Nirlaba (Studi Kasus pada SMK Negeri 4 Malang). Journal Riset Mahasiswa Akuntansi Vol. 2, No. 1. ISSN 23375663.

Yuhaida, Husnia Novia. 2015. Penerapan Laporam Keuangan Organisasi Nirlaba Berdasarkan PSAK No. 45 (Studi Kasus pada Lembaga Pendidikan Ma'arif NU Assalbiyah). Jember: Universitas Jember. 